Lepr Rev (1983) Special Issue, 17S-22S

\title{
Bacteriology of Mycobacterium leprae
}

\author{
S R PATTYN \\ Institute for Tropical Medicine, Antwerp and University of Antwerp, \\ Antwerp, Belgium
}

Summary A review is presented on the morphologic features, chemical characteristics, growth capacity, drug sensitivity, metabolic activity and antigen structure of Mycobacterium leprae. Since the availability of large numbers of $M$. leprae from armadillo tissue, knowledge, particularly on the chemical characteristics has increased. It may be expected that knowledge on the metabolic activities will increase, leading perhaps, one day, to the long-awaited in vitrocultivation of the organism.

\section{Morphology}

Classically Mycobacterium leprae is stained by the Ziehl-Neelsen method, and shows up as an acid-alcohol-fast (AAF) rod 0.3-0.4 $\mu \mathrm{m} \times 2-7 \mu \mathrm{m}$. Metachromatic granules may be observed. The molecular basis for the acid-alcohol fastness has not been elucidated although it is generally believed to be related to the cell wall composition, particularly the mycolic acids. Nocardia containing nocardomycolic instead of mycolic acids, differing mainly from mycolic acids by a shorter carbon chain length, are not AAF, although this difference is not absolute: some individual cells of nocardiae may appear acid-fast, while some mycobacterial species, particularly the rapidly growing ones, may contain a fraction of non-acid-fast organisms.

It has been claimed ${ }^{1}$ that treatment of $M$. leprae containing preparations with periodic acid renders more organisms stainable by an acid-fast staining technique. It has been shown ${ }^{2}$ that such organisms are present in human biopsy material but that the failure of staining by the standard acid-fast technique is a characteristic of dead $M$. leprae unable to infect the mouse footpad, whereas organisms recovered from mouse footpads during their logarithmic multiplication, stain equally well by the standard technique as after periodate treatment.

It was claimed ${ }^{3,4}$ that treatment of $M$. leprae containing smears with pyridine rendered them non-acid-fast while all other mycobacteria tested are "pyridinefast'. There has been some controversy on this point ${ }^{5,6}$ but it seems now that the 
reaction is valid if highly purified pyridine is used as shown by McCormick and Sanchez. ${ }^{7}$

Most M. leprae organisms are also granular. It has long been thought that these irregularly staining bacteria are degenerate, dead forms, particularly since during the later phases of treatment, in patients who are approaching bacteriological negativity, only AAF 'dust' can be found. Rees and co-workers ${ }^{8,9}$ showed in an elegant series of experiments that this is indeed the case and this has been amply confirmed by use of the mouse footpad technique: granular, 'non-solid' forms of $M$. leprae are degenerate, unviable. ${ }^{10}$ This has led to the notion of the morphologic index. ${ }^{11}$ However, determination of the morphologic index requires carefully standardized fixation and staining techniques, the use of a perfectly regulated microscope and very careful examination of 100-200 individual bacteria, a practice only attainable in reference laboratories and not realizable in field conditions.

In thin sections $M$. leprae has a cell wall $15-20 \mathrm{~nm}$ thick consisting of two electron-dense layers and an outer electron-transparent layer. Mesosomes continuous with the cytoplasmic membrane are sometimes numerous, but their function and meaning is unknown, they might even be artefacts. ${ }^{12}$

In electron microscopy the walls of $M$. leprae may show band-like structures parallel to the short axis of the cell ${ }^{13}$ and 'paired fibrous structures' ${ }^{14}$ Electron microscopic examination of tissues infected with $M$. leprae has established the presence of an electron-transparent zone surrounding the bacilli ${ }^{15-17}$ which may be considered as a capsule of $M$. leprae, composed of a specific mycoside. ${ }^{18,19}$

\section{Chemical structure of cell walls}

The wall of Mycobacterium leprae consists of peptidoglycan ${ }^{20}$ to which are attached arabinogalactan (polysaccharide) chains bearing mycolic acids. Associated lipids are phosphatidyl-inositol-mannosides (PIM), attenuation indicator lipid (AIL), phtioldimycocerosate (DIM) and mycoside.

The cross-linking tetrapeptides in the peptidoglycan are unique: only half of the usual amount of alanine is present, and this is present as the D-enantiomer, while equimolar amounts of glycine are present, suggesting that the L-alanine in the $M$. leprae peptidoglycan tetrapeptide is replaced by glycine. This structure is rare and is found in some plant pathogenic corynebacteria. ${ }^{12}$ The mycolic acids of $M$. leprae are also different from those of other mycobacteria in that they contain only $\alpha$ - and keto-mycolates ${ }^{21,22}$ whereas other mycobacteria have 3 mycolates.

Phosphatidyl-inositol-mannosides (PIM) which occur in all corynebacteria, nocardiae and mycobacteria have also been found in M. leprae ${ }^{23}$ as well as DIM, phtioldimycocerate and AIL, attenuation indicator lipid, a methylated-phenol- 
phtiocerol-dimicocerosate, originally found in attenuated strains of $M$. tuberculosis. ${ }^{23,24}$

Finally, the mycoside of $M$. leprae is closely related to mycoside A from $M$. kasasii, but contains a different and unique trisaccharide composed of 3,6-di-Omethylglucose, 3-O-methylrhamnose (both not previously found in nature) and 3,6-di-O-methylglucose. ${ }^{19}$ Large quantities of the glycolipid are also present in infected armadillo liver residue freed of $M$. leprae, suggesting that it may correspond to the electron-transparent zone surrounding the organism in infected tissue. ${ }^{19}$ All in all many particularities of the chemical structure of $M$. leprae have now been revealed. They should be most usef ul for the identification of claims concerning in vitro grown strains of $M$. leprae.

Recently, the first results on DNA studies of $M$. leprae were published. ${ }^{25}$ The genome size was $1 \cdot 1-3 \cdot 2 \times 10^{9}$, the $\mathrm{G}+\mathrm{C}$ content ranged from 55.6 to $71.5 \mathrm{~mol} \%$. Homology of $M$. leprae DNA was higher with a strain of corynebacteria $(68.4 \%)$ than with mycobacteria of which $M$. tuberculosis and M. scrofulaceum showed the highest homology: $51 \cdot 8 \%$ and $57.9 \%$ respectively. Clearly, these results await confirmation.

\section{Growth}

Mycobacterium leprae multiplies in the cooler parts of the body of mice, rats and hamsters: footpads, ears and testicles, with a generation time during the logarithmic phase of 12-14 days. ${ }^{26}$ The minimal infective dose in the mouse footpad (MFP) is 1-3 organisms ${ }^{10}$ and growth stops when $\pm 10^{6}$ bacilli are present. Rees ${ }^{27}$ has shown in the very early years of the MFP era that this limitation was of an immunologic nature, and introduced the immunosuppressed mouse (thymectomized and irradiated). In these animals multiplication of $M$. leprae continues beyond the $10^{6}$ ceiling in the MFP and gives rise to generalized infection with all the characteristcs of lepromatous leprosy in man. ${ }^{27,28}$ The same occurs more rapidly after intravenous injection. Later other immunosuppressed rodents were introduced: the newborn thymectomized Lewis rat, ${ }^{29}$ the athymic mouse $\mathrm{e}^{30,31}$ and the athymic rat (Colston, unpublished).

Immunosuppressed rodents have been mainly used to detect small numbers of viable $M$. leprae among large numbers of dead bacilli in patients $\mathrm{u}$ so called persisters, because in these animals large numbers of even dead bacilli do not lead to an immune response, arresting the growth of a small inoculum of viable $M$. leprae. (Recently it has been shown that normal mice can also serve this purpose. $)^{32}$ Kirschheimer $\&$ Storrs $^{33}$ found that a high proportion of nine-banded armadillos (Dasypus novemcinctus) is sensitive for Mycobacterium leprae and develop a generalized infection, particularly when intravenously injected. Klingmüller \& Sobich $^{34}$ found that this is also the case in the hedgehog (Erinaceus europeus) as confirmed by McDougall et al. ${ }^{35}$ 
The availability of large amounts of Mycobacterium leprae from armadillos has allowed all the chemical analyses referred to above and opened perspectives for the development of an antileprosy vaccine.

\section{Drug sensitivity}

Strains of Mycobacterium leprae from previously untreated patients, isolated during the 1960's, were all very sensitive to dapsone: $0.0001 \%$ in the diet producing serum concentrations of $0.01-0.03 \mathrm{~g} / 1 .{ }^{36}$ This situation is now much changed due to the widespread and increasing occurrence of secondary and primary dapsone resistance.

Minimal inhibitory concentrations of other drugs for wild strains of $M$. leprae have been determined, the pattern of which is characteristic for M. leprae. ${ }^{37}$

\section{Metabolic activities}

There has been much debate about the metabolic activity of Mycobacterium leprae recovered from human biopsies. Now that greater amounts of bacteria can be purified from infected armadillo livers, it may be expected that considerable progress will be made in this field in the near future. Prabhakaran et al. ${ }^{38}$ detected a dopa (3,4-dihydroxyphenylalanine) oxidase in $M$. leprae, confirmed by autoradiographic studies. ${ }^{39}$ Wheeler \& Gregory ${ }^{40}$ could not detect catalase in $M$. leprae, but a low activity peroxidase and a superoxide dismutase (more easily detected at $\mathrm{pH} 7 \cdot 8$ than at $\mathrm{pH} 10$ ).

\section{Antigenic structure}

Immunodiffusion studies did not show any specific antigens in Mycobacterium leprae. ${ }^{41}$ Antigens detected by crossed immunoelectrophoresis cross-react with other mycobacteria, with a particular situation for antigen 21 related to $M$. tuberculosis..$^{42}$ However, mycoside A from M. leprae has recently been shown to be a suitable antigen for taxonomic and perhaps serological studies. ${ }^{18,19,43}$

\section{References}

${ }^{1}$ Nyka W. Method for staining both acid-fast and chromophobic tubercle bacilli with carbolfuchsin. J Bacteriol, 1967; 93: 1458.

${ }^{2}$ Levy L, Hom C, Murray LP. Enumeration of Mycobacterium leprae stained with and without prior periodate oxidation. Lepr Rev, 1976; 47: 185-91.

3 Fisher AH, Barksdale L. Elimination of the acid-fastness but not the gram-positivity of leprosy bacilli after extraction with pyridine. J Bacteriol, 1971; 106: 707-8. 
${ }^{4}$ Convit J, Pinardi ME. A simple method for the differentiation of Mycobacterium leprae from other mycobacteria through routine staining techniques. Int J Lepr, 1972; 40: 130-2.

${ }^{5}$ Skinsness OK, Chang PHC, Matsuo E. Acid-fast properties and pyridine extraction of $M$. leprae. Int J Lepr, 1975; 43: 339-47.

${ }^{6}$ Slosarek M, Sula L, Theophilus S, Hruby L. Use of pyridine for differentiating Mycobacterium leprae from other mycobacteria in direct microscopy. Int J Lepr, 1978; 46: 154-9.

7 McCormick GT, Sanchez RT. Pyridine extractability of acid-fastness from Mycobacterium leprae. Int J Lepr, 1979; 47: 495-9.

8 Rees RJW, Valentine RC, Wong PC. Application of quantitative electron microscopy to the study of Mycobacterium lepraemurium and M. leprae. J Gen Microbiol, 1960; 22: 443-57.

9 Rees RJW, Valentine RC. The appearance of dead leprosy bacilli by light and electron microscopy. Int J Lepr, 1962; 30: 1-9.

10 Shepard CC, McRae DH. Mycobacterium leprae in mice: minimal infectious dose, relationship between staining quality and infectivity and effect of cortisone. $J$ Bacteriol, 1965; 89: 365-72.

${ }^{11}$ Rees RJW, Ridley DS. Bacteriology and pathology of leprosy. In SC Dyke (ed.), Recent Advances in Clinical Pathology (Series 6), pp. 305-21. Edinburgh: Churchill Livingstone, 1973.

12 Draper P. The anatomy of mycobacteria. In C Ratledge, J Stanford (eds). The Biology of the Mycobacteria, pp. 9-52. London-New York: Academic Press, 1982.

13 Nishiura M, Okada S, Isumi S, Takazawa H. An electron microscope study of the band structure of the leprosy bacillus and other mycobacteria. Int J Lepr, 1969; 37: 225-38.

${ }^{14}$ Gordon J, White RG. Surface peptidoglycolipid filaments on Mycobacterium leprae. Clin exp Imm, 1971; 9: 539-47.

15 Sato S, Imi M. The surface structure of Mycobacterium leprae. Int J Lepr, 1968; 36: 303-8.

${ }^{16}$ Edwards P. Electron-microscope illustrations of division in Mycobacterium leprae. $J$ Med Microbiol, 1970; 77: 79-87.

17 Yoshizumi MD, Ashbury AK. Intra-axonal bacilli in lepromatous leprosy. Acta Neuropathol, 1974; 27: 1-10.

18 Brennan PJ, Barrow WW. Evidence of species-specific lipid antigens in Mycobacterium leprae. Int J Lepr, 1980; 48: 382-7.

${ }^{19}$ Hunter SW, Brennan PJ. A novel glycolipid from Mycobacterium leprae possibly involved in immunogenicity and pathogenicity. $J$ Bacteriol, 1981; 47: 728-35.

${ }^{20}$ Draper P. Cell walls of Mycobacterium leprae. Int J Lepr, 1976; 44: 95-8.

${ }^{21}$ Etemadi AH, Convit J. Mycolic acids from 'noncultivable' mycobacteria. Infect Immun, 1974; 10: $236-9$.

22 Young DB. Identification of Mycobacterium leprae: use of wall-bound mycolic acids. J Gen Microbiol, 1980; 121: 249-53.

${ }^{23}$ Young DB. Detection of mycobacterial lipids in skin biopsies from leprosy patients. Int $J$ Lepr. 1981; 49: 198-204.

${ }^{24}$ Goren MB, Broke O, Schaeffer WB. Lipids of putative relevance to virulence in Mycobacterium tuberculosis: phtiocerol dimycoserosate and attenuation indicator lipid. Inf Imm, 1974; 9: $150-8$.

${ }^{25}$ Imaeda T, Kirschheimer WF, Barksdale L. DNA isolated from Mycobacterium leprae: genome size, base ratio and homology with other related bacteria as determined by optical DNA-DNA reassociation. J Bacteriol, 1982; 150: 414-17.

${ }^{26}$ Shepard CC. The experimental disease that follows the injection of human leprosy bacilli into foot-pads of mice. J exp Med, 1960; 112: 445-54.

${ }^{27}$ Rees RJW. Enhanced susceptibility of thymectomized and irradiated mice to infection with Mycobacterium leprae. Nature (Lond), 1966; 211: 657-8.

${ }^{28}$ Rees RJW, Waters MFR, Weddell AGM, Palmer E. Experimental lepromatous leprosy. Nature (Lond), 1967; 215: 599-601. 
${ }^{29}$ Fieldsteel AH, Levy L. Neonatally thymectomized Lewis rats infected with Mycobacterium leprae: response to primary infection, secondary challenge and large inocula. Inf Imm, 1976; 14: $736-41$.

${ }^{30}$ Colston JJ, Hilson GRF. Growth of Mycobacterium leprae and M. marinum in congenitally athymic (nude) mice. Nature, 1976; 262: 399-401.

${ }^{31}$ Kohsaka K, Mori T, Ito T. Lepromatoid lesion developed in nude mouse inoculated with Mycobacterium leprae. Int J Le pr, 1976; 44: 540.

32 Fieldsteel AH, Colston MJ. The intact mouse as a host for the detection of small numbers of viable Mycobacterium leprae in the presence of large numbers of heat-killed M. leprae. Int $J$ Lepr, 1981; 49: 499-500.

${ }^{33}$ Kirschheimer WF, Storrs EE. Attempts to establish the armadillo (Dasypus novemcinctus) as a model for the study of leprosy. I. Report of lepromatoid leprosy in an experimentally infected armadillo. Int J Lepr, 1971; 39: 693-702.

${ }^{34}$ Klingmüller S, Sobich E. Uebertragung menschlicher Leprabakterien auf den Igel. Naturw, 1977; 64: 645.

${ }^{35}$ McDougall AC, Rees RJW, Lowe C. Preliminary histopathological data on experimental Mycobacterium leprae infections in the hedgehog. J Med Microb, 1979; 12: p. VII.

36 Levy L, Peters JH. Susceptibility of Mycobacterium leprae to dapsoneas: a determinant of patient response to acedapsone. Antim Ag Chemother, 1976; 9: 102-12.

37 Portaels F, Pattyn SR. Taxonomy of Mycobacterium leprae and M. lepraemurium. Ann Microb (Inst Pasteur), 1982; 133B: 99-108.

${ }^{38}$ Prabhakaran K, Harris EB, Kirschheimer WF. O-diphenoloxidase of Mycobacterium leprae separated from infected armadillo tissues. Inf Imm, 1975; 12: 267-9.

39 Ambrose EJ, Antia NH, Khanolkar SR. Uptake of radioactive dopa by Mycobacterium leprae. Nature (Lond), 1974; 249: 854-5.

40 Wheeler PR, Gregory D. Superoxide dismutase, peroxidase activity and catalase in Mycobacterium leprae purified from armadillo liver. J Gen Microbiol, 1980; 121: 457-64.

${ }^{41}$ Stanford JL, Grange JM. The meaning and structure of species as applied to mycobacteria. Tubercle (Lond), 1974; 55: 143-52.

42 Widebäck K, Kronvall G, Bjorvatn B, Closs O, Harboe M. Comparative studies of antigen 21 in Mycobacterium and Nocardia species: possible taxonomic relationships with Mycobacterium leprae. Inf Imm, 1980; 30: 413-20.

43 Payne SN, Draper P, Rees RJW. Serological activity of purified glycolipid from Mycobacterium leprae. Int J Lepr, 1982; 50: 220-1. 